UDC 629.7:339.187.6 (045)

DOI: https://doi.org/10.32782/2520-2200/2019-5-3

\author{
Kyrylenko Oksana \\ National Aviation University \\ Tkachyk Yehor \\ National Aviation University
}

Кириленко О.М.

доктор економічних наук, професор, завідувач кафедри менеджменту ЗЕДП Національного авіаційного університету

Ткачик $\Theta . A$.

студент

Національного авіаційного університету

\title{
TRENDS AND FORECAST OF THE DEVELOPMENT OF GLOBAL AND THE EU AVIATION LEASING MARKETS
}

\section{ТЕНДЕНЦІЇ ТА ПРОГНОЗ РОЗВИТКУ СВІТОВОГО ТА ЄВРОПЕЙСЬКОГО РИНКІВ АВІАЛІЗИНГУ}

This scientific article is devoted to studying the current state of development of the aircraft leasing market around the world, and provision of its basic forecast for the future. The main period under review covers 2012-2018, which show the main trends in the development of aviation leasing, in particular, major regions such as North America, the EU, Europe and Central Asia, the Middle East and North Africa, East Asia and the Pacific, Latin America and Caribbean, South Africa, South Asia. Article also examines the current state of the air transportation market and explains the main relationship and importance of using direct financing and leasing in the field of air transportation. In addition, the main statistics of the aviation market are considered. Further, the article reveals regional problems and features of air transportation in different regions. Next, a full-size analysis of the influence of the banking sector of developed countries on financing the aviation industry, in particular leasing, is carried out. The share of the largest participants in financing the aviation industry is displayed, the thesis of the importance of the Chinese market is expressed. Assumptions are given on future patterns of aviation industry development, and the centers of gravity of the main air traffic flow in the world are indicated. The article ends with the disclosure of training topics in the field of aircraft leasing and summing up the future development of aviation leasing.

Key words: aviation leasing, centers of gravity, international aviation market, passenger transportation, bank loans, IATA.

Ця наукова стаття присвячена вивченню сучасного стану розвитку ринку лізингу літаків у всьому світі та наданню прогнозу його розвитку у майбутньому. Основний період, що переглядається, охоплює 2012-2018 роки, де відображаються основні тенденції розвитку авіаційного лізингу, зокрема такі основні регіони, як Північна Америка, ЄС, Європа та Центральна Азія, Близький Схід та Північна Афррика, Східна Азія та Тихий океан, Латинська Америка та Карибський басейн, Південна Афррика, Південна Азія. Недавній прогноз Міжнародної асоціації повітряного транспорту (IATA) щодо розвитку авіаційних пасажирських перевезень на найближчі 20 років свідчить про те, що Азіатсько-Тихоокеанський регіон стане джерелом генерування більше половини світового повітряного пасажирського потоку протягом наступних двадцяти років. Близько 2029 року Китай відсуне США поза позиції найбільшого світового ринку авіації, що визначається загальним обсягом міжнародного та внутрішнього авіаперевезень. Стаття також вивчає сучасний стан ринку повітряних перевезень та пояснює основні взаємозв'язки та важливість використання прямого фрінансування та лізингу у сфері повітряних перевезень. Крім того, розглядається основна статистика авіаційного ринку. Далі у статті розкриваються регіональні проблеми та особливості авіаперевезень у різних регіонах. Далі проводиться повномасштабний аналіз впливу банківського сектора розвинених країн на фрінансування авіаційної галузі, зокрема лізингу. Показана частка найбільших учасників фрінансування авіаційної галузі, висловлена теза про важливість китайського ринку. Дані припущення щодо майбутніх закономірностей розвитку авіаційної галузі, а також зазначаються центри тяжкості основного потоку повітряного руху у світі. Стаття закінчується роз- 
криттям навчальних тем у галузі лізингу літаків та підведенням підсумків майбутнього розвитку авіаційного лізингу.

Ключові слова: авіалізинг, центри тяжіння, міжнародний авіаційний ринок, пасажирські перевезення, банківські позики, IATA.

Данная научная статья посвящена изучению текущего состояния развития рынка лизинга воздушных судов по всему миру, и предоставлению базового прогноза его развития в будущем. Основной рассматриваемый период охватывает 2012-2018 годы, которые показывают основные тенденции развития авиализинга, в частности рассматриваются основные регионы, такие, как Северная Америка, ЕС, Европа и Центральная Азия, Ближний Восток и Северная Африка, Восточная Азия и Тихий океан, Латинская Америка и Карибский Бассейн, Южная Африка, Южная Азия. В статье раскрываются региональные проблемы и особенности авиаперевозок в разных регионах. Далее проводится полноразмерный анализ влияния банковского сектора развитых стран на финансирование авиационной отрасли, в частности лизинга. Заканчивается статья раскрытием темы подготовки кадров в сфере лизинга воздушных судов и подведением итогов о будущем развития авиализинга.

Ключевые слова: авиализинг, центры притяжения, международный авиационный рынок, пассажирские перевозки, банковские займы, ИАТА.

Formulation of the problem. The aviation market can be seen as a complex system, consisting of a subset of a number of subsystems, some of which are independent, and some form mutually intersecting sets that have a common segment. The segmentation of the aviation leasing market itself can be based on various characteristics: types of airliners, types of airlines and the distance of routes, types of leasing itself, the amount of income of leasing companies, and the geography of leasing. The above signs play a different, and in some cases a multidirectional role. That is, if the influence of a factor on one segment of aviation leasing is positive and contributes to its growth (development), then on the other segment the same factor can act with opposite consequences, depressing. In the process of a comprehensive analysis of the dynamics of the aviation market, a whole range of different indices and methods is used. Among them are SWOT analysis and Porter's Five Forces Analysis, price analysis and others.

Analysis of recent research and publications. The theoretical basis of the study was the work of the founders of leasing theory: Majer B., Hamel

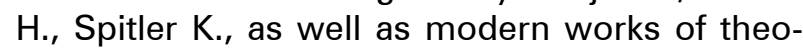
rists and practitioners in the field of the leasing services market, such as Ammembal S., Anderson B., Berger T., Blum D., Bubier K., Day A., Drew P., Clark T. More general problems, namely: airport finances and the potential for global investment in the aviation industry are considered in the works of foreign authors. Leasing issues, incl. its various forms are covered in a large number of studies, primarily of an informational and analytical nature, however, the current problems and prospects of aviation proper itself are covered in a rather fragmented way in the scientific literature. So, the works of such authors as Afanasyev V.G.,
Goremykin V.A., Gubenko A.V., Dzhuha V.M., Kurnosov A.M., Kabatova E.V., are devoted to the general problems of aircraft leasing in Russia. Leshchenko M.I.

The aim of the article is trends and forecast of the development of global and the EU aviation leasing markets.

Main research material of the article. The total fleet of the world, as of August 2018, amounted to 9,589 vessels, which were leased by $108 \mathrm{com}$ mercial lessors from 143 countries of the world flying on 772 airlines. The combined orders of these lessors totaled 2,738 airliners on the same date. The average age of leased vessels was 11.4 years. At the same time, $5.7 \%$ of the entire fleet was in reserve and not operated. A high concentration is observed in the aviation leasing market: a large number of airliners belong to a limited number of lessor companies. Table 1 summarizes the factors that have a significant impact on the development of aviation in the global economy.

The global aviation market, its dynamics and structure are influenced by numerous factors of both a macroeconomic nature and the consumer sector. The latter include the income of the population, the level and quality of life, one of the modern characteristics of which is the need for travel as a fast-growing form of leisure and recreation. Obviously, the increase in passenger flows directly affects the size of the fleet in the global economy, and, accordingly, the growth of aviation leasing, including international. The regions are presented in table 1 in a ranked form: by gross national income indicator, taking into account purchasing power parity (PPP) in US dollars 2017. At the same time, the regional division is based on the approach of organizations of the UN system. In addition to macro-regions, the European Union (EU) has been allocated for comparative analysis. 
Factors impacting the development of aviation in the global economy

\begin{tabular}{|c|c|c|c|c|c|c|}
\hline \multirow[b]{2}{*}{ Region } & \multirow[b]{2}{*}{$\begin{array}{c}\text { Population, } \\
\text { mln. }\end{array}$} & \multirow{2}{*}{$\begin{array}{c}\text { Air } \\
\text { Transport, } \\
\text { carried } \\
\text { passengers, } \\
\text { mln. }\end{array}$} & \multirow{2}{*}{$\begin{array}{l}\text { International } \\
\text { tourism, } \\
\text { expenses for } \\
\text { passenger } \\
\text { transport, } \\
\text { mln. USD }\end{array}$} & \multirow{2}{*}{$\begin{array}{l}\text { Air transport, } \\
\text { cargo } \\
\text { transportation, } \\
\text { mln. tons-km }\end{array}$} & \multicolumn{2}{|c|}{$\begin{array}{l}\text { GNI per capita, } \\
\text { thnd. USD }\end{array}$} \\
\hline & & & & & $\begin{array}{l}\text { Atlas } \\
\text { method } \\
\text { current, } \\
\text { USD }\end{array}$ & $\begin{array}{c}\text { By PPP, } \\
\text { internat., } \\
\text { USD }\end{array}$ \\
\hline North America & 357 & 878,5 & 43626 & 39293,7 & 54,3 & 55,2 \\
\hline EU & 509 & 653,4 & 69553 & 33339,9 & 34,4 & 37,6 \\
\hline $\begin{array}{l}\text { Europe and } \\
\text { Central Asia }\end{array}$ & 907 & 878,8 & 80283 & 42641,6 & 24,1 & 29,5 \\
\hline $\begin{array}{l}\text { Middle East and } \\
\text { North Africa }\end{array}$ & 424 & 217,2 & 14138 & 28509,1 & 8,2 & 18,8 \\
\hline $\begin{array}{l}\text { East Asia and } \\
\text { the Pacific }\end{array}$ & 2279 & 1043,4 & 43712 & 66350,7 & 9,6 & 15,7 \\
\hline $\begin{array}{l}\text { Latin America } \\
\text { and the } \\
\text { Caribbean }\end{array}$ & 632 & 260,2 & 16568 & 5730,8 & 8,9 & 15,3 \\
\hline South Africa & 55 & 17,2 & 3145 & 885,2 & 6,1 & 12,8 \\
\hline South Asia & 1744 & 117,8 & & 2619,2 & 1,5 & 5,6 \\
\hline
\end{tabular}

It seems that the EU needs to be highlighted also because the World Bank (WB. It is no coincidence that the hopes of the largest air carriers for the sustainable development of international tourism, and, consequently, international aviation leasing, are associated with the growth of the middle class in this region, whose population is 6.4 times the population of North America and 4.5 times the population of the EU. From the table it follows that the population of the region "Latin America and the Caribbean" is satisfied with a low "aviation activity". At the same time, the population of the above region is 1.77 times the population of North America, and $24 \%$ of the EU. Nevertheless, the passenger flow in the Asia-Pacific countries was 3.38 times lower than that of the regions of North America and Europe and Central Asia, and 2.5 times lower than the EU. It should be noted that the South Asia region unites countries that are very different from each other in terms of their economic power. And if, for example, in India, the aviation leasing market is still gaining momentum, then in China it is already quite developed, and Chinese aviation leasing companies can already compete with the largest aviation leasing companies in the global market. If from the point of view of the size of passenger traffic the above-mentioned countries are clearly not among the leaders, then the Asia-Pacific countries are ahead of all other regions in terms of freight traffic (million ton-kilometers) by air. Aviation leasing and the financing of the aviation industry are two closely related economic institutions. Experts believe that the volume of financing for deliveries to the global aviation market will increase from US \$ 127 billion in 2016 to US \$ 172 billion in 2020, and fairly rapid changes will occur in the structure of transaction financing. In particular, we are talking about increasing the number of low-cost airlines. Lowcost airlines are considered to be the key drivers of growth in aviation leasing and passenger traffic in general, both in the present and in the foreseeable future. At the same time, it should be noted that 2015 turned out to be very unfavorable for these carriers, and their share in the general global passenger transportation market decreased from $25.9 \%$ to $25.4 \%$. Nevertheless, prior to this period, continuous growth was observed, including the crisis years of 2008 and 2009, and in general, the share of low-budget companies increased from $8.0 \%$ in 2001 to $25.4 \%$ in 2015, i.e. 3.18 times. But not only the above mentioned indicators are important for assessing the role of low-cost airlines in the aviation market. Much more important is their regional distribution. With this, to some extent, the deployment of airlines is the main consumers of operating leasing services. The South-East $(56 \%)$ and South Asia $(54 \%)$ regions are leading in the quantitative growth of low-cost airlines. Europe, which is in third place, lags significantly behind with its $39 \%$, but Latin America is close to it $-36 \%$. In North America, the figure is at the global average - $25 \%$, in the Middle East $20 \%$. The lowest rates are observed in Northeast Asia $(10 \%)$, Africa $(9 \%)$ and China (7\%). Regarding China, it should be noted that such low numbers are associated not with the lack of demand for low-cost services, but with the legislative restrictions of this institution. On the contrary, in India, for obvious reasons, the share of low-cost airlines 
on local airlines is $62 \%$ of the passenger flow. In general, over the past 10 years, the average annual growth rate of the number of low-cost airlines in Asia amounted to $24 \%$, which is 4 times higher than the global average.

Traditional sources of financing for aviation leasing are: loans from commercial banks, capital markets, loans from export credit agencies, funds from aircraft manufacturing companies. New sources of financing for leasing include loans from regional development banks, funds from large regional lessors, Islamic financing, investments from institutional investors such as sovereign and pension funds, and investments from hedge funds. The role in financing the aviation operations of commercial banks from Asian countries and the Middle East is growing. If we talk about the country structure of banks actively involved in the financing of aviation leasing, we note that these are mainly the most developed countries. Banks of other countries provide only $20 \%$ of transactions in the world market, while the maximum share of these 20 percent is provided by Chinese banks. It is worth noting banks in Germany, Japan, France, the United States and Australia (8\%). According to Boeing analysts, lessors will continue to use the stock market and bank loans as the main sources of capital in the coming years. Moreover, the amount of financing provided by commercial banks will increase due to an increase in the share of deliveries of airliners to China, where bank lending prevails. The distribution of bank loans by country is shown in Figure 1

In 2018, international air transportation amounted to 4 billion passenger kilometers, and domestic - 2 billion passenger kilometers. International tourism is a powerful incentive for the development of airlines and, accordingly, the

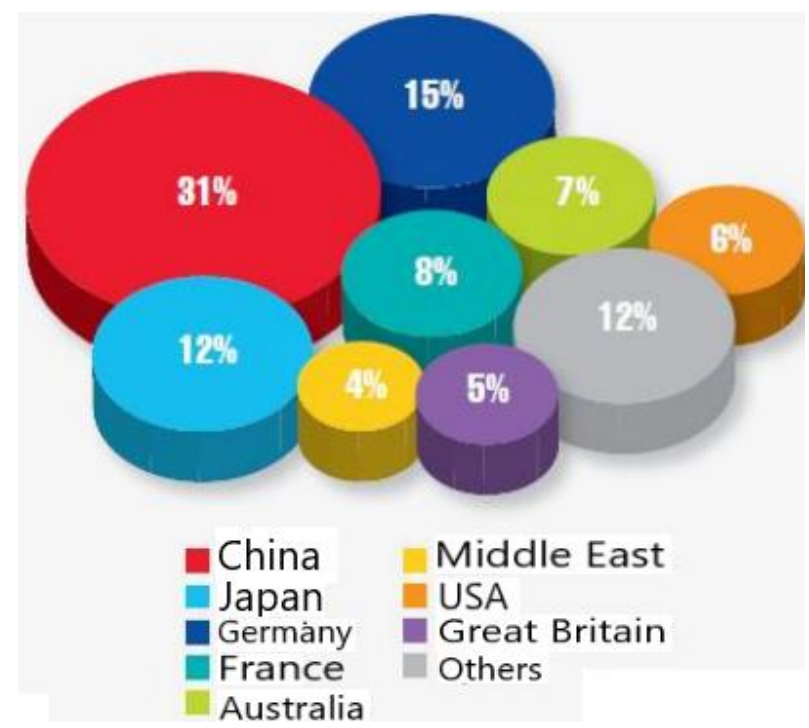

Fig. 1 The distribution of bank loans by countries airline market. According to the World Tourism Organization (UNWTO), 54\% of all tourists use air transport. Europe takes the first place in the number of arrivals of international tourists and in the amount of cash receipts from them. But if on arrivals in 2018 it held an absolute majority $-51 \%$, then revenues from international tourism amounted to about $36 \%$ of world income or $\$ 448$ billion, while the share of the Asia-Pacific region was $34 \%$ or $\$ 419$ billion. The possibilities of air leasing, in addition to those already considered and related directly to the three parties to economic, financial and legal relations, are also determined by the need for airlines in airplanes, depending on the demand for their services from direct consumers. The geographical distribution of the population and its demand for air transportation vary greatly, which is, as can be assumed, primarily due to the incomes of the population in a particular region. Members of the United Nations Economic Commission for Europe (ECE) include, among others, such countries as Ukraine, as well as 3 Transcaucasian states - Azerbaijan, Armenia, Georgia. The countries of Central Asia, including the EAEU members (Kazakhstan and Kyrgyzstan), are included in the Asia region and the countries of the Pacific basin.

When discussing aircraft leasing market it is important to understand main directions in which air transportation sphere will develop. A recent International Air Transport Association (IATA) forecast for the development of aviation passenger traffic for the next 20 years indicates that the Asia-Pacific region will be the source of generating more than half of the global air passenger flow over the next twenty years.

Around 2029, China will move aside the United States out of the position of the world's largest aviation market, determined by the total volume of international and domestic air traffic.

Along with this, India will rise to the second step in 2026, displacing Britain, while Indonesia will enter the TOP-10, and Italy will no longer be among the ten largest markets.

IATA expects that by 2035 there will be 7.2 billion passengers a year in the world, which is almost $65 \%$ more than in 2018. Such a forecast is based on a global aggregate average annual growth rate - CAGR - of $3.7 \%$. This indicator reflects the growth rate of investments over a certain period of time. The forecast emphasizes that the Asia-Pacific region will be the largest driver of development and demand.

The dominant trend of changes in the development direction the global leasing market is evidenced by current statistics and existing forecasts of international organizations and individual experts. 
According to Western experts, aircraft leasing became a serious business in the 70 s of the twentieth century, when the leased aircraft fleet began to number 100 aircraft around the world. Founded in 1975, GPA (Guinness Peat Aviation) was perhaps the first mega-company to rent airliners. The company was founded in Ireland, still the headquarters of many leasing companies. Unfortunately, the recession in the aviation industry following the Persian Gulf War (1991) led the GPA to withdraw from the leasing market.

In just 7 years, including 2011-2018, the share of the leasing fleet increased by almost 5 percentage points (4.72), and the share of the fleet of own aircraft decreased accordingly, while global GDP grew by $32 \%$ and GDP of developed countries (OECD group) - by $17.1 \%$. Consequently, if we calculate the average growth rate of the leasing fleet for the period 2011-2018, then it amounted to $102.2 \%$, which is slightly higher than the annual growth rates of world GDP (PPP) - a little more than $2 \%$, and the OECD group indicators (PPP) slightly below $2 \%$

As for the sources of financing the activities of airlines, they are represented by the following institutions: leasing companies themselves, the capital market, private assets, commercial banks, export credit agencies, hedge funds, etc. 2011 turned out to be very difficult for aviation companies in terms of attracting sources financing for their core business. In subsequent years, the situation gradually improved and in the period from 2016 to 2018. airline owners felt quite comfortable financially. As for export credit agencies, even during the acute phase of the crisis, they did not lack financial resources. The same can be said about hedge funds. For the class of private assets, it is difficult to single out any definite trend; rather, the situation was characterized by significant fluctuations in the volume of invested funds. Commercial banks provided loans to airlines, but very selectively, since their profitability even in the most favorable periods for the development of air transport is very low, and therefore the free cash flow is not so large, which leads to risks of increasing the debt load.

Lessors of the fleet are not always direct registered owners of the aircraft of their fleet, and property (ownership) is often associated with special purpose companies (SPC).

In general, this sector of the economy measures the size of leased air fleets by the number of aircraft under management. The system is configured as if the tenant - the airline could be the "operator", SPC - the "co-owner", and the leasing company - the "manager". There are more than 150 lessors in the world, but just under two-thirds of the leased fleet is managed by the 15 largest leasing companies (lessors). Many leasing companies are owned by financial institutions or private shareholders.

In the last decade, there has been a sharp increase in landlords who have come under capital control from Asian countries (Japan, China, Hong Kong), including SMBC, Boca, ICBC and Avalon. In addition to the expected return on investment income (which is usually made in hard currency, primarily in US dollars) in aircraft, these investments are considered as protection against currency fluctuations, especially the devaluation of some Asian currencies.

One of the important trends in the development of the global aviation leasing market is the training of highly qualified personnel for this sector of the economy. In 2016, the first ever graduation of Masters in Aviation Finance took place, which is now taught at UCD's Smurfit Business School. The most significant role in the development of training highly qualified personnel in the world belongs to the Irish Academy of the famous Tony Ryan - DCU Ryan Academy. Ireland occupies the highest positions, or, as one of the aviation research researchers Gavin McLoughlin figuratively writes, "flies high" in the field of aircraft leasing, including in preparing management for this industry

According to most experts, by 2034 the rich Middle East will come out in the number of large airliners - 208 units, Asia will be in the second place - 182 cars, but the Indian subcontinent will be in third place, where India takes the leading place - 155 units, and only in 4th place is China 143 units, Europe -148 units will lag behind just a little, and the CIS fleet will have 133 such airliners, which also seems significant both for national lessors and manufacturers of this equipment.

If we turn to the agreement on air transportation concluded between the countries for the period from 1945 to 2017, it becomes obvious that they provide a significant increase in flights carrying passengers and goods to the countries participating in these agreements (for example, the agreement between China and ASEAN, signed in 2010 , led to an increase between the two sides of the routes and the number of airports they covered from 78 to 156). Such a quantitative increase in routes and destinations could not but affect the number of aircraft leased.

Since 2014, AerCap has become the largest lessor in the world market in terms of total asset value, which has bypassed the constant leader of GECAS by only $\$ 600$ million. The same advantage remained in 2015. It should also be noted that already 38 leasing companies have an air fleet in the global market that exceeds the cost of $\$ 1$ billion. 
Conclusions. It must be emphasized that macroeconomic factors and their adverse changes can adversely affect the state of specific markets. In particular, in the aviation leasing market, despite its growth as a whole, a negative trend manifested itself in the excess of the supply of aviation objects over demand, which was largely due to a drop in oil prices, respectively, for aviation fuel, as a result of which the operators were able to fulfill their obligations to deliver passengers, operating fewer airliners, but more intensively. That is, aviation as a part of the aviation industry is forced to reckon with the emerging restrictions and seek a way out in a more complex approach to development schemes and the mechanism of interaction between aircraft manufacturers and air carriers.

\section{References:}

1. Perevezennya pasazhyriv i pasazhyrooborot za sichen-gruden 2013-2017 rr. (Mizhnarodni ta vnutrishni perevezennya) [Passenger transportation and passenger traffic for January-December 2013-2017 (International and domestic transportation)]. Federal Air Transport Agency. Available at: http://www.favt.ru/public/materials//3/a/6/3/d/3a63db604433371c3ce667c5f5f058 1b.pdf (accessed 1 October 2019).

2. Dodatok 6 do Konvenciyi pro mizhnarodnu cyvilnu aviaciyu. Ekspluataciya povitryanyx suden [Annex 6 to the Convention on International Civil Aviation. Operation of aircraft]. ICAO. 2008. 158 p. Available at: http://airspot.ru/book/file/576/an06_p2_cons_7ed_ru.pdf (accessed: 10.02.2019).

3. Khodorkovskyj, A. Novi aviacijni realiyi [New aviation realities]. ATO Business Aviation Portal. RU. November 21, 2014. Available at: http://www.ato.ru/ (accessed: 01.10.2019).

4. Annual Reports 2014. Air Lease Corporation. 2015. 76 p. Available at: http://www.airleasecorp.com/ files/press/AL_2014AR3.pdf (accessed 02.10.2019).

5. Annual Reports 2015. Air Lease Corporation. 2016. 78 p. Available at: http://www.airleasecorp.com/ files/press/AL_2015AR.pdf (accessed 02.10.2019).

6. Annual Reports 2016. Air Lease Corporation. 2017. 60 p. Available at: http://www.airleasecorp.com/ files/documents/AirLease2016Annual_Report_eBlue.pdf (accessed 02.10.2019).

7. Aircraftleasing.CivilAviationAuthority.2018.Av̄ailableat:http://www.caa.co.uk/Commerciallndustry/ Aircraft/Leasing/Aircraft-leasing/ (accessed 04.10.2019).

8. Commercial aircraft leasing. World Leasing Yearbook. 2016. 8 p. Access mode: https://www.dvbbank.com/ /media/Files/D/Dvb-Bank-Corp/dvb-inpress/2016/world-leasingyearbook-2016-060416.pdf (accessed 07.11.2016).

\section{Список використаних джерел:}

1. Перевезення пасажирів і пасажирооборот за січень-грудень 2013-2017 рр. (Міжнародні та внутрішні перевезення). Федеральне агентство повітряного транспорту. URL: http://www.favt.ru/public/materials//3/a/6/3/d/3a63db604433371c3ce667c5f5f058 1b.pdf (дата звернення: 01.10.2019).

2. Додаток 6 до Конвенції про міжнародну цивільну авіацію. Експлуатація повітряних суден. IKAO. 2008. 158 p. URL: http://airspot.ru/book/file/576/an06_p2_cons_7ed_ru.pdf (дата звернення: 02.10.2019).

3. Ходорковський А. Нові авіаційні реалії. Авіатранспортний огляд. Діловий авіаційний портал ATO. RU. 21 листопада 2014. URL: http://www.ato.ru/ (дата звернення: 01.10.2019).

4. Annual Reports 2014. Air Lease Corporation. 2015. 76 p. URL: http://www.airleasecorp.com/files/ press/AL_2014AR3.pdf (дата звернення: 02.10.2019).

5. Annual Reports 2015. Air Lease Corporation. 2016. 78 p. URL: http://www.airleasecorp.com/files/ press/AL_2015AR.pdf (дата звернення: 02.10.2019).

6. Annual Reports 2016. Air Lease Corporation. 2017. 60 p. URL: http://www.airleasecorp.com/files/ documents/AirLease2016Annual Report eBlue.pdf (дата звернення: 02.10.2019).

7. Aircraft leasing. Civil Aviation Aūthority. 2018. URL: http://www.caa.co.uk/Commerciallndustry/Aircraft/Leasing/Aircraft-leasing/ (дата звернення: 04.10.2019 p).

8. Commercial aircraft leasing. World Leasing Yearbook. 2016. 8 p. URL: https://www.dvbbank.com/ / media/Files/D/Dvb-Bank-Corp/dvb-inpress/2016/world-leasing-yearbook-2016-060416.pdf (дата звернення: 05.10.2019). 